\title{
Mashare - The People
}

This factsheet is based on data collected from 2011 to 2013. The quantitative data source is the TFO Socio-Economic Baseline Survey (SEBS) conducted on 291 randomly sampled households in the greater Mashare area (Fig. 1). The area includes seven settlements: Tjeye (with its own headwoman), Mashare, Katondo, and Muroro, under the authority of the Mashare headman, as well as Mahahe, Mupapama and Masivi, under the authority of the Mahahe headman. Qualitative data on farming practices were gathered through interviews and focus groups with key informants, especially knowledgeable farmers and men/women of the community $(\mathrm{N}=32)$.
Table 1: General information and key figures for the greater Mashare area.

\begin{tabular}{|ll|}
\hline Total number of households & Estimated number of individuals/ population size \\
\hline 518 & 3,216 \\
\hline Average household size & Size of study area \\
\hline 6 & $96.33 \mathrm{~km}^{2}$ \\
\hline Population density (persons $\left./ \mathrm{km}^{2}\right)$ & Ratio of children : adults : seniors \\
\hline 33 & $0.45: 0.45: 0.1$ \\
\hline Average age for total population $(\mathbf{N}=1811)$ & $\begin{array}{l}\text { Median education level adult (age }>18) \\
\text { population }\end{array}$ \\
\hline 27 years & Finished primary school \\
\hline Dependency ratio* & Sex ratio for total population \\
\hline 102.1 & 83.8 \\
\hline Child-woman-ratio* & \\
\hline 542.6 & \\
\hline
\end{tabular}

* Definition of the indicators in Electronic Appendix

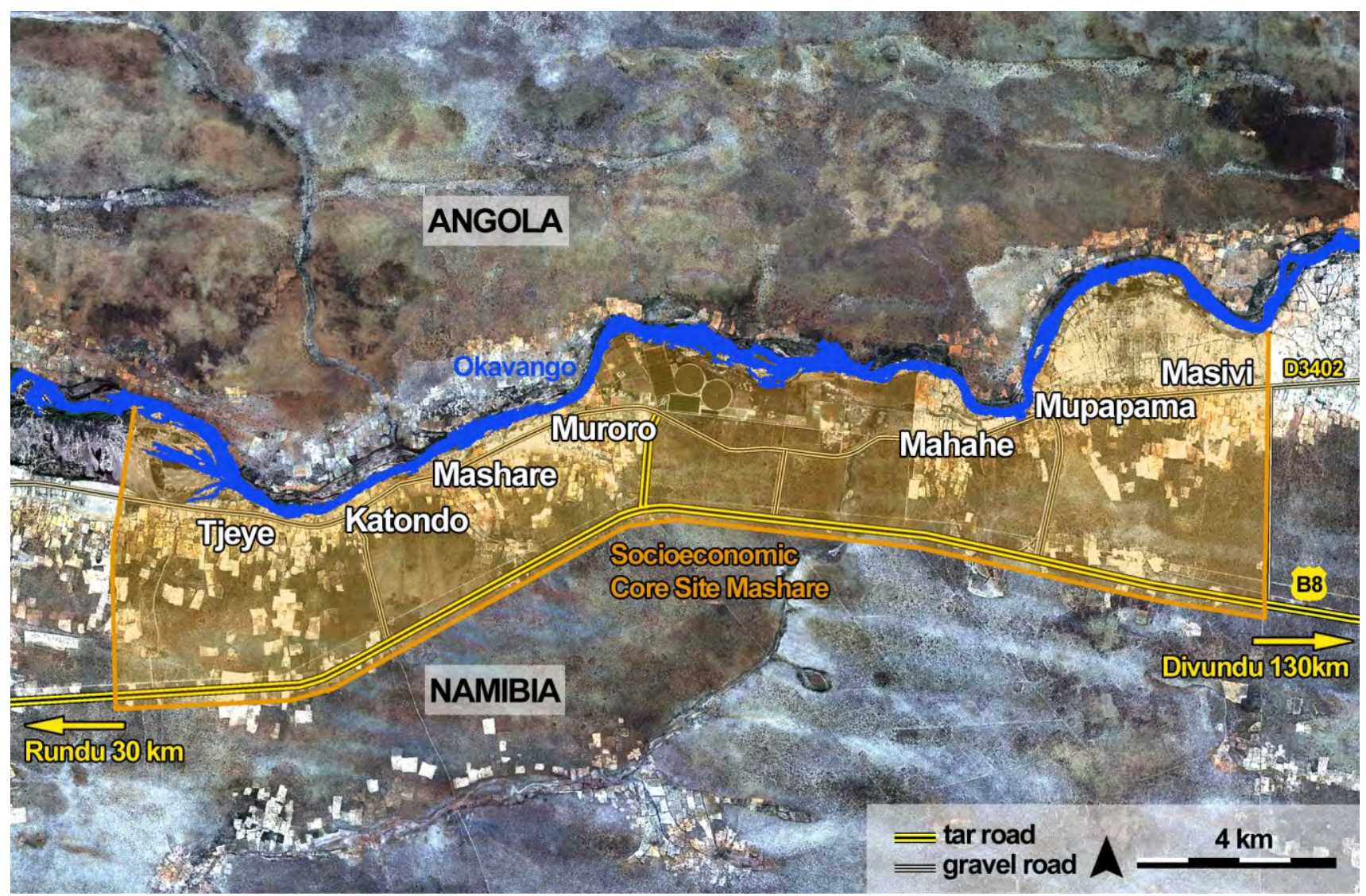

Fig. 1: Location of the seven settlements of the socio-economic TFO core site, organized within three villages. Map designed by Jan Wehberg. 
This section presents livelihood strategies of the inhabitants of the core site. The people of the Mashare core site draw their livelihood from arable agriculture, livestock keeping, the use of natural resources and wage labor, mostly as casual workers in the private sector or as regular employees in the public sector. Few own a private business. Further sources of cash include pensions (old age pension, disability grant, and orphanage), remittances, business (beer and food retailers), sale of livestock and crops, and, to a lesser extent, transfers and trade of natural resources. Households combine these different options in very individual ways to make a living. The identification of livelihood strategies was based on the six following variables representing livelihood options using cluster analysis as a statistical tool:

- Does the household practice agriculture or horticulture? (Y/N)

\section{Main livelihood strategies in the Mashare core site society}

The majority of households are established in the area of study for more than twenty years. On average, as much as $40 \%$ of the households have female headship. Although located only $45 \mathrm{~km}$ from the urban centre and capital of the WestKavango region, Rundu, a hub of consumerism and trade, life in Mashare is dominated by subsistence farming and living conditions are basic. The river is the main source of water for most households. Similarly, firewood is the prime energy source for more than $95 \%$ of the households, while only a minority has access to energy sources such as diesel generators or the electricity grid. The level of education is generally low, especially among household heads. Despite these similarities in wealth and living standards, livelihood strategies can be divided into six clusters which we group here, for an improved understanding, into three categories.

The first category consists of relatively wealthy livestock owners. These households have predominantly male headship, have comparably large herds of cattle and goats and regular access to cash income. They use natural resources mainly for subsistence and construction purposes, and practice arable agriculture. Among them, a first cluster (1- successful rural allrounders) stands out due to the elevated income the households generate from employment in the public sector or through business activities. They consist mainly of young and wealthy men. The second cluster (2- welloff smallholders) depicts households who generate a much lower and less regular income through casual work or employment in the private sector, which they complement with the retail of livestock and agricultural products.

In the second category, we find poorer households with few livelihood options who rely mainly on arable agriculture. This category comprises a higher proportion of households headed by women than average. Cash transfers, remittances and government pensions play an important role for these household economies. Among them, the third cluster (3- lowincome smallholders) comprises the least educated households in the core site. These households do not own cattle, which is a strong disadvantage for field cultivation, but have small numbers of goats or poultry. Natural resources are important, though mainly for subsistence and not for retail. Their cash income is is low and consists mainly of pensions, transfers and regular employment in the private sector. Households of the fourth cluster (4- poor farmers) do not own any livestock and their
-Does the household own any livestock? (Y/N)

- Does the household own cattle? (Y/N)

- Does the household sell or exchange natural resources?(Y/N)

- (Per capita amount of) Annual cash income from employment.

- (Per capita amount of) Annual cash income from private businesses.

use of natural resources as well as their access to cash appears to be very low. If they are involved in any off-farm work, it is irregular casual work, which is supplemented with pensions and remittances as other sources of cash income.

The third category seems to have a greater focus on cash-based livelihood options than the others. Within this category, a fifth cluster (5-rural self-made (wo)men) can be identified through its natural resources retail and irregular employment, which, complemented by livestock sales, ensure the majority of households' cash income - albeit at rather low overall income levels. Indeed, half of these households own livestock and the majority practices arable agriculture. In contrast, the sixth cluster (6- households using few ESS) gathers together all households that do not practice agriculture nor make use of natural resources, but strongly rely on cash income. Within this group we identified two opposite sub-clusters: (1) households who rely solely on employment (i.e. "aspiring urbanites") and (2) households who are dependent on government pensions (i.e. "the very poor"), including the marginalized San households. If any of these households own livestock, it is in small numbers of goats or poultry. 
Characteristics of households in each of the six livelihood strategy clusters

\begin{tabular}{|c|c|c|c|c|c|c|c|}
\hline & $\begin{array}{l}\text { (1) } \\
\text { Successful } \\
\text { rural } \\
\text { allrounders }\end{array}$ & $\begin{array}{l}\text { (2) } \\
\text { Well-off } \\
\text { small- } \\
\text { holders }\end{array}$ & $\begin{array}{l}(3) \\
\text { Low-income } \\
\text { small- } \\
\text { holders }\end{array}$ & $\begin{array}{c}\text { (4) } \\
\text { Poor } \\
\text { farmers }\end{array}$ & $\begin{array}{l}\text { (5) } \\
\text { Rural } \\
\text { self-made } \\
\text { (wo)men }\end{array}$ & $\begin{array}{l}(6) \\
\text { Housholds } \\
\text { using } \\
\text { few ESS }\end{array}$ & $\begin{array}{l}\text { Total } \\
\text { sample }\end{array}$ \\
\hline \multicolumn{8}{|l|}{ Cluster information } \\
\hline Number of households in cluster & 15 & 79 & 85 & 64 & 14 & 34 & 291 \\
\hline Share of households in sample & $5 \%$ & $27 \%$ & $29 \%$ & $22 \%$ & $5 \%$ & $12 \%$ & $100 \%$ \\
\hline \multicolumn{8}{|l|}{ General household attributes } \\
\hline $\begin{array}{l}\text { Share of households residing in } \\
\text { Mashare for less than } 20 \text { years }\end{array}$ & $33 \%$ & $18 \%$ & $13 \%$ & $24 \%$ & $14 \%$ & $18 \%$ & $18 \%$ \\
\hline Mean household size & 5.9 & 7.0 & 6.4 & 6.3 & 5.1 & 4.5 & 6.2 \\
\hline $\begin{array}{l}\text { Share of households with female } \\
\text { headship }\end{array}$ & $33 \%$ & $28 \%$ & $46 \%$ & $50 \%$ & $36 \%$ & $42 \%$ & $40 \%$ \\
\hline Dependency ratio* & 152.8 & 117.3 & 117.4 & 108.2 & 97.4 & 102.1 & 102.1 \\
\hline \multicolumn{8}{|l|}{$\begin{array}{l}\text { Household's mother tongue } \\
\left.\text { [share } /\left(\mathrm{n}^{\circ}\right)\right]\end{array}$} \\
\hline Nyemba & $27 \%(4)$ & $47 \%(37)$ & $28 \%(24)$ & $44 \%(28)$ & $29 \%(4)$ & $24 \%(8)$ & $36 \%(105)$ \\
\hline Kwangali & $33 \%(5)$ & $15 \%(12)$ & $35 \%(30)$ & $19 \%(12)$ & $50 \%(7)$ & $32 \%(11)$ & $26 \%(77)$ \\
\hline Shambyu & $27 \%(4)$ & $24 \%(19)$ & $21 \%(18)$ & $22 \%(14)$ & $21 \%(3)$ & $21 \%(7)$ & $22 \%(65)$ \\
\hline Gciriku & $13 \%(2)$ & $6 \%(5)$ & $12 \%(10)$ & $11 \%(7)$ & $0 \%(0)$ & $18 \%(6)$ & $10 \%(30)$ \\
\hline San & $0 \%(0)$ & $0 \%(0)$ & $0 \%(0)$ & $0 \%(0)$ & $0 \%(0)$ & $6 \%(2)$ & $1 \%(2)$ \\
\hline Tjokwe & $0 \%(0)$ & $5 \%(4)$ & $0 \%(0)$ & $2 \%(1)$ & $0 \%(0)$ & $0 \%(0)$ & $2 \%(5)$ \\
\hline Ovambo & $0 \%(0)$ & $1 \%(1)$ & $1 \%(1)$ & $0 \%(0)$ & $0 \%(0)$ & $0 \%(0)$ & $1 \%(2)$ \\
\hline Mixed ethnics & $0 \%(0)$ & $1 \%(1)$ & $2 \%(2)$ & $3 \%(2)$ & $0 \%(0)$ & $0 \%(0)$ & $2 \%(5)$ \\
\hline \multicolumn{8}{|l|}{ Household welfare } \\
\hline $\begin{array}{l}\text { Share of households where } \\
\text { highest level of education among } \\
\text { adults does not go beyond "Finished } \\
\text { primary school“ }\end{array}$ & $27 \%$ & $49 \%$ & $61 \%$ & $56 \%$ & $71 \%$ & $61 \%$ & $55 \%$ \\
\hline $\begin{array}{l}\text { Share of households where } \\
\text { education level of household head } \\
\text { does not go beyond "Finished } \\
\text { primary school" }\end{array}$ & $50 \%$ & $88 \%$ & $92 \%$ & $87 \%$ & $86 \%$ & $85 \%$ & $87 \%$ \\
\hline $\begin{array}{l}\text { Share of households using modern } \\
\text { sources of energy (gas, electricity, } \\
\text { solar panel, diesel generator) for } \\
\text { cooking, heating, lighting }\end{array}$ & $20 \%$ & $4 \%$ & $4 \%$ & $0 \%$ & $7 \%$ & $3 \%$ & $3 \%$ \\
\hline $\begin{array}{l}\text { Share of households using the river } \\
\text { as main source of water }\end{array}$ & $73 \%$ & $58 \%$ & $66 \%$ & $60 \%$ & $64 \%$ & $68 \%$ & $63 \%$ \\
\hline $\begin{array}{l}\text { Share of households with at least } \\
\text { one modern house (no use of local } \\
\text { natural resources) }\end{array}$ & $33 \%$ & $8 \%$ & $5 \%$ & $2 \%$ & $0 \%$ & $6 \%$ & $6 \%$ \\
\hline $\begin{array}{l}\text { Mean (median) asset } \\
\text { endowment (max. } 20 \text { items) }\end{array}$ & $5.5(5)$ & $3.7(4)$ & $3.3(3)$ & $2.5(3)$ & $2.7(3)$ & $1.6(1)$ & $3.1(3)$ \\
\hline $\begin{array}{l}\text { Mean (median) days with } \\
\text { consumption of meat (max. 30) }\end{array}$ & $10.9(5)$ & $3.6(3)$ & $3.7(3)$ & $1.8(0.5)$ & $4.7(3.5)$ & $1.9(0)$ & $3.5(2)$ \\
\hline $\begin{array}{l}\text { Mean (median) days with } \\
\text { consumption of fish (max. 30) }\end{array}$ & $11(10)$ & $9.4(7)$ & $10.7(10)$ & $6.9(4)$ & $10(10)$ & $5.8(4)$ & $8.9(7)$ \\
\hline
\end{tabular}




\begin{tabular}{|c|c|c|c|c|c|c|c|}
\hline & $\begin{array}{l}\text { (1) } \\
\text { Successful } \\
\text { rural } \\
\text { allrounders }\end{array}$ & $\begin{array}{l}\text { (2) } \\
\text { Well-off } \\
\text { small- } \\
\text { holders }\end{array}$ & $\begin{array}{l}\text { (3) } \\
\text { Low-income } \\
\text { small- } \\
\text { holders }\end{array}$ & $\begin{array}{c}\text { (4) } \\
\text { Poor } \\
\text { farmers }\end{array}$ & $\begin{array}{l}\text { (5) } \\
\text { Rural } \\
\text { self-made } \\
\text { (wo)men }\end{array}$ & $\begin{array}{l}\text { (6) } \\
\text { Housholds } \\
\text { using } \\
\text { few ESS }\end{array}$ & $\begin{array}{l}\text { Total } \\
\text { sample }\end{array}$ \\
\hline \multicolumn{8}{|l|}{ Household use of natural resources } \\
\hline $\begin{array}{l}\text { Share of households practicing } \\
\text { arable agriculture }\end{array}$ & $100 \%$ & $100 \%$ & $100 \%$ & $100 \%$ & $86 \%$ & $0 \%$ & $88 \%$ \\
\hline $\begin{array}{l}\text { Share of households owning } \\
\text { livestock }\end{array}$ & $93 \%$ & $100 \%$ & $100 \%$ & $0 \%$ & $50 \%$ & $29 \%$ & $67 \%$ \\
\hline $\begin{array}{l}\text { Mean (median) number of } \\
\text { cattle owned }\end{array}$ & $33.8(14)$ & $15.7(11)$ & $0(0)$ & $0(0)$ & $8.4(8)$ & $0(0)$ & $17.6(11.5)$ \\
\hline $\begin{array}{l}\text { Mean (median) number of } \\
\text { goats owned }\end{array}$ & $41.1(45)$ & $13.5(8.5)$ & $10.6(5)$ & $0(0)$ & $26(26)$ & $5(5)$ & $15.3(8)$ \\
\hline $\begin{array}{l}\text { Mean (median) monetary per } \\
\text { capita value of natural resources } \\
\text { harvest (with OECD equivalence } \\
\text { scale, in US\$) }\end{array}$ & $\begin{array}{c}\$ 1,327 \\
(\$ 2,482)\end{array}$ & $\begin{array}{l}\$ 210 \\
\$ 213\end{array}$ & $\begin{array}{c}\$ 213 \\
(\$ 176)\end{array}$ & $\begin{array}{l}\$ 152 \\
(\$ 68)\end{array}$ & $\begin{array}{l}\$ 313 \\
(\$ 450)\end{array}$ & $\begin{array}{c}\$ 62 \\
(\$ 18)\end{array}$ & $\begin{array}{c}\$ 243 \\
(\$ 144)\end{array}$ \\
\hline $\begin{array}{l}\text { Mean (median) number of } \\
\text { wild food resources used }\end{array}$ & $3.3(3)$ & $4.1(5)$ & $4.4(5)$ & $3.6(4)$ & $4.6(5)$ & $3.1(3.5)$ & $3.9(4)$ \\
\hline $\begin{array}{l}\text { Mean (median) number of } \\
\text { natural resources used for } \\
\text { building }^{*}\end{array}$ & $3.3(4)$ & $3.8(4)$ & $3.9(4)$ & $3.8(4)$ & $3.9(4)$ & $2.9(3)$ & $3.7(4)$ \\
\hline \multicolumn{8}{|l|}{ Household economic situation } \\
\hline $\begin{array}{l}\text { Mean (median) annual disposable } \\
\text { per capita cash income (with OECD } \\
\text { equivalence scale, in US\$) }\end{array}$ & $\begin{array}{c}\$ 5,329 \\
(\$ 3,748)\end{array}$ & $\begin{array}{c}\$ 798 \\
(\$ 481)\end{array}$ & $\begin{array}{c}\$ 509 \\
(\$ 382)\end{array}$ & $\begin{array}{c}\$ 450 \\
(\$ 363)\end{array}$ & $\begin{array}{l}\$ 689 \\
(\$ 564)\end{array}$ & $\begin{array}{l}\$ 945 \\
(\$ 505)\end{array}$ & $\begin{array}{l}\$ 883 \\
(\$ 431)\end{array}$ \\
\hline $\begin{array}{l}\text { Mean (median) share of business } \\
\text { income in annual disposable house- } \\
\text { hold cash income (in \%) }\end{array}$ & $31 \%(0 \%)$ & $10 \%(0 \%)$ & $5 \%(0 \%)$ & $6 \%(0 \%)$ & $5 \%(0 \%)$ & $1 \%(0 \%)$ & $7 \%(0 \%)$ \\
\hline $\begin{array}{l}\text { Mean (median) share of salary in- } \\
\text { come in annual disposable house- } \\
\text { hold cash income (in \%) }\end{array}$ & $46 \%(48 \%)$ & $24 \%(0 \%)$ & $24 \%(0 \%)$ & $30 \%(0 \%)$ & $34 \%(0 \%)$ & $33 \%(0 \%)$ & $28 \%(0 \%)$ \\
\hline $\begin{array}{l}\text { Mean (median) annuall per capita } \\
\text { income from retail of natural resour- } \\
\text { ces (with OECD equivalence scale, } \\
\text { in US\$) }\end{array}$ & $\$ 0(\$ 0)$ & $\$ 0(\$ 0)$ & $\$ 0(\$ 0)$ & $\$ 1(\$ 0)$ & $\$ 57(\$ 58)$ & $\$ 0(\$ 0)$ & $\$ 3(\$ 0)$ \\
\hline $\begin{array}{l}\text { Share (number) of households } \\
\text { with regular access to cash (addi- } \\
\text { tional irregular access possible) }\end{array}$ & $93 \%(14)$ & $71 \%(56)$ & $65 \%(55)$ & $53 \%(34)$ & $43 \%(6)$ & $62 \%(21)$ & $64 \%(186)$ \\
\hline with irregular access to cash* & $7 \%(1)$ & $28 \%(22)$ & $32 \%(27)$ & $34 \%(22)$ & $57 \%(8)$ & $24 \%(8)$ & $30 \%(88)$ \\
\hline without access to cash* & $0 \%(0)$ & $1 \%(1)$ & $4 \%(3)$ & $13 \%(8)$ & $0 \%(0)$ & $15 \%(5)$ & $6 \%(17)$ \\
\hline
\end{tabular}

* Definition of the indicators in Electronic Appendix

\section{The farming system in Mashare}

Despite an increasing livelihood diversification in the core site, animal husbandry and arable agriculture remain highly important livelihood sources for the vast majority of households. This can be attributed both to the multi-functionality of livestock keeping (esp. cattle, see below) and the role of subsistence farming as a back-up / survival strategy in the face of market imperfections (limited access to, or high volatility of, wage labour and consumergoods markets). However, adverse environmental conditions (high rainfall variability / very low soil fertility) make farming a challenging business that rarely covers a household's annual food needs.

As a quick characterization, farmers in the core site can be described as predominantly subsistence oriented smallholders, practicing mixed cropping of millet (Pennisetum glaucum) and a variety of secondary crops (mainly legumes) on a few hectares with small livestock herds in a system of semi-permanent rainfed agriculture. 


\section{Facts on the farming system}

\section{Farming system classification}

Semi-permanent cultivation (a late stage of a relatively high permanence)

\section{Location of fields and settlements}

- Stationary housing within scattered villages along the river.

- Homesteads often located within or next to cropping areas.

\section{Dominant cropping pattern}

Mixed cropping of millet (Pennisetum glaucum) and a wide variety of secondary crops (legumes, pumpkin...).

\section{Complementary cropping patterns}

Mixed cropping of maize (Zea mays) or sorghum (Sorghum sp.) with a wide variety of secondary crops (legumes, pumpkin...)

\section{General farm management characteristics}

- Farmers adapt to nature and do not try to adapt nature to the needs of farming.

- Households share the same basic agricultural practices, but follow very individual strategies for soil fertility

management and crop rotation.

- Main challenges of arable farming: rainfall variability / land scarcity / lack of draught animal power

$\rightarrow$ reduced field sizes \& yields (late planting, wasting earlier rains, increasing pest pressure).

- Main challenges of animal husbandry: diseases \& rangeland degradation (high mortality).

\section{Main farming implements}

Manual, hoe-based cultivation with ox-drawn ploughs for soil preparation.

\section{Cultivation/Fallow cycle}

- Permanent cropping with rare and irregular short-term fallows (of 1-2 years, often caused by necessity, i.e. drought, illness, lack of draught animal power).

- Limited potential to extend arable area (low soil fertility \& problematic water access).

\section{Crop rotation}

- Practiced irregularly, usually when crop productivity deteriorates.

- Limited possibilites, as most soils allow only for cultivation of millet and legumes.

\section{Soil fertility management}

Current practices insufficient to retain fertility $\rightarrow$ soil degradation (a few households practice a sophisticated fertility management by combining practices)

- Most common practices:

1) Application of household wastes on fields directly around homesteads.

2) Regular rotation of livestock kraals on fields to fertilise with manure.

3) Incorporation of crop residues and cleared vegetation into soil during ploughing.

4) Livestock feeding on crop residues, fertilizing to a limited degree with manure.

5) Burning of cleared vegetation.

6) Planting of legumes.

7) Short-term fallow (1-2 years).

8) Acquisition of fresh soil by clearing new or extending old fields (limited potential).

- Generally:

9) No intentional fertility management at all, farming relatively stable at low yields.

\section{Land tenure}

- Communal land tenure.

- "General use right" of community members on community land (e.g. for collection of natural resources, livestock grazing).

- Exclusive "household-specific use right" as long as allocated land is under management (incl. fallow periods of 10+ years).

- Unmanaged land can be reallocated to other community members.

\section{Livestock economy}

Livestock keeping, esp. cattle, an important livelihood source due to its multi-functionality: draught animal power / social function (prestige, brideprice)/risk-coping strategy ("rural bank account").

\section{Cattle management}

- Herding during growing season - free range system during rest of the year - kraaling at night.

- Grazing on: harvest residues/fallow lands/natural vegetation. No fodder cropping.

\section{"Cattle crisis"}

Recent breakdown of local cattle economy a typical feature in late stages of tropical semi-permanent cultivation systems (see Ruthenberg 1971). Caused by unsustainable communal grazing practices. 


\section{Cultivated crops}

Table 2: Crops cultivated in Mashare core site and frequency of cultivation among households ( $\mathrm{N}=255$ ) (Latin names derived according to best knowledge from FAO (2010) World Census of Agriculture).

\begin{tabular}{|c|c|c|c|c|}
\hline & Crops & Latin name & $\begin{array}{l}\text { Frequency } \\
(\mathrm{N}=255)\end{array}$ & $\begin{array}{c}\% \text { of cultivating } \\
\text { households }\end{array}$ \\
\hline \multirow{3}{*}{ Cereals } & Millet & Pennisetum glaucum & 252 & 98.4 \\
\hline & Maize & Zea mays & 229 & 89.5 \\
\hline & Sorghum & Sorghum bicolor & 107 & 41.8 \\
\hline Pulses & Beans \& Cowpeas & no specification & 196 & 76.6 \\
\hline Oil seeds & $\begin{array}{l}\text { Groundnuts (African } \\
\text { groundnuts or peanuts) }\end{array}$ & $\begin{array}{l}\text { Arachis hypogaeal } \\
\text { Vigna subterranea }\end{array}$ & 175 & 68.4 \\
\hline \multirow[t]{2}{*}{ Tubers } & Potatoes & Solanum tuberosum & 1 & 0.4 \\
\hline & Sweet potatoes & Ipomea batatas & 1 & 0.4 \\
\hline \multirow[t]{11}{*}{ Vegetables } & Pumpkin & Cucurbita spp. & 34 & 13.3 \\
\hline & Hibiscus & species unknown & 14 & 5.5 \\
\hline & Rupotera & species unknown & 11 & 4.3 \\
\hline & Onions & Allium cepa & 5 & 2.0 \\
\hline & Cabbage & Brassica sp. & 4 & 1.6 \\
\hline & Carrot & Daucus carota ssp. sativa & 2 & 0.8 \\
\hline & Green pepper & species unknown & 2 & 0.8 \\
\hline & Cucumber & Cucumis sp. & 1 & 0.4 \\
\hline & Chili & Capsicum spp. (annuum) & 1 & 0.4 \\
\hline & Beet root & Beta vulgaris & 1 & 0.4 \\
\hline & Ntjies & species unknown & 1 & 0.4 \\
\hline \multirow[t]{9}{*}{ Fruits } & Melon (water melon \& others) & Citrullus vulgaris \& Cucumis melo & 10 & 3.9 \\
\hline & Tomatoes & Lycopersicon esculentum & 5 & 2.0 \\
\hline & Sugar cane & Saccharum sp. & 2 & 0.8 \\
\hline & Bananas & Musa paradisiaca & 1 & 0.4 \\
\hline & Papaya (pawpaw) & Carica papaya & 1 & 0.4 \\
\hline & Apple & Malus sylvestris & 1 & 0.4 \\
\hline & Orange & Citrus sinensis & 1 & 0.4 \\
\hline & Guava & Psidium guajava & 1 & 0.4 \\
\hline & Grape & Vitis vinifera & 1 & 0.4 \\
\hline
\end{tabular}

Cultivated crops influence the diversity of the diet of the farming communities, as they constitute the main share of the consumed food products. They can also be a source of income. The data refer to the core site of Mashare and include only subsistence farmers (commercial farming was excluded from this sample).

In general, 27 different crops are cultivated in total in the Mashare core site (Tab. 2). However, only 9 crops are cultivated by at least 10 households and among them only 4 crops are cultivated by more than $50 \%$ of the households. These are pearl millet (Kwangali: Mahangu), maize, beans and groundnuts. The large majority of households produce for selfsubsistence with $70 \%$ cultivating only 3 to 5 crops (Fig. 2). The most important crops for subsistence are millet, beans and hibiscus leaves (Kwangali: Mutete). About

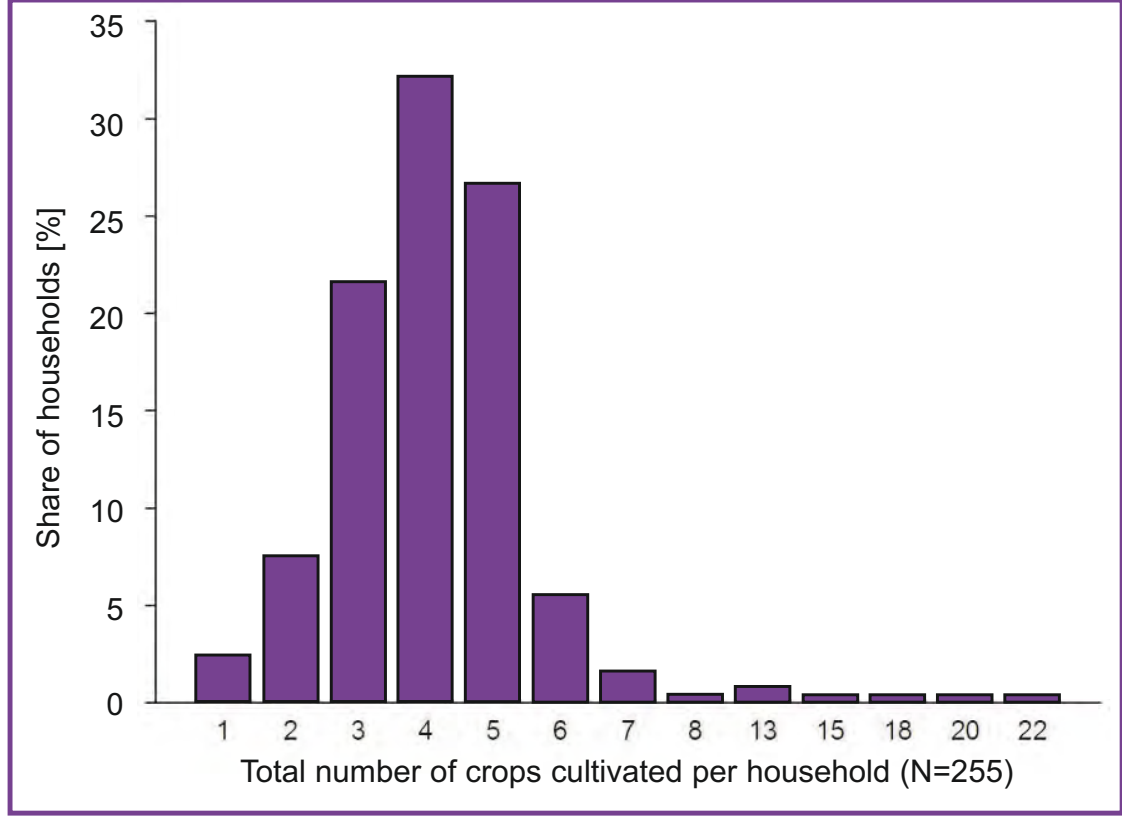

Fig. 2: Distribution among households of the diversity of crops cultivated. 


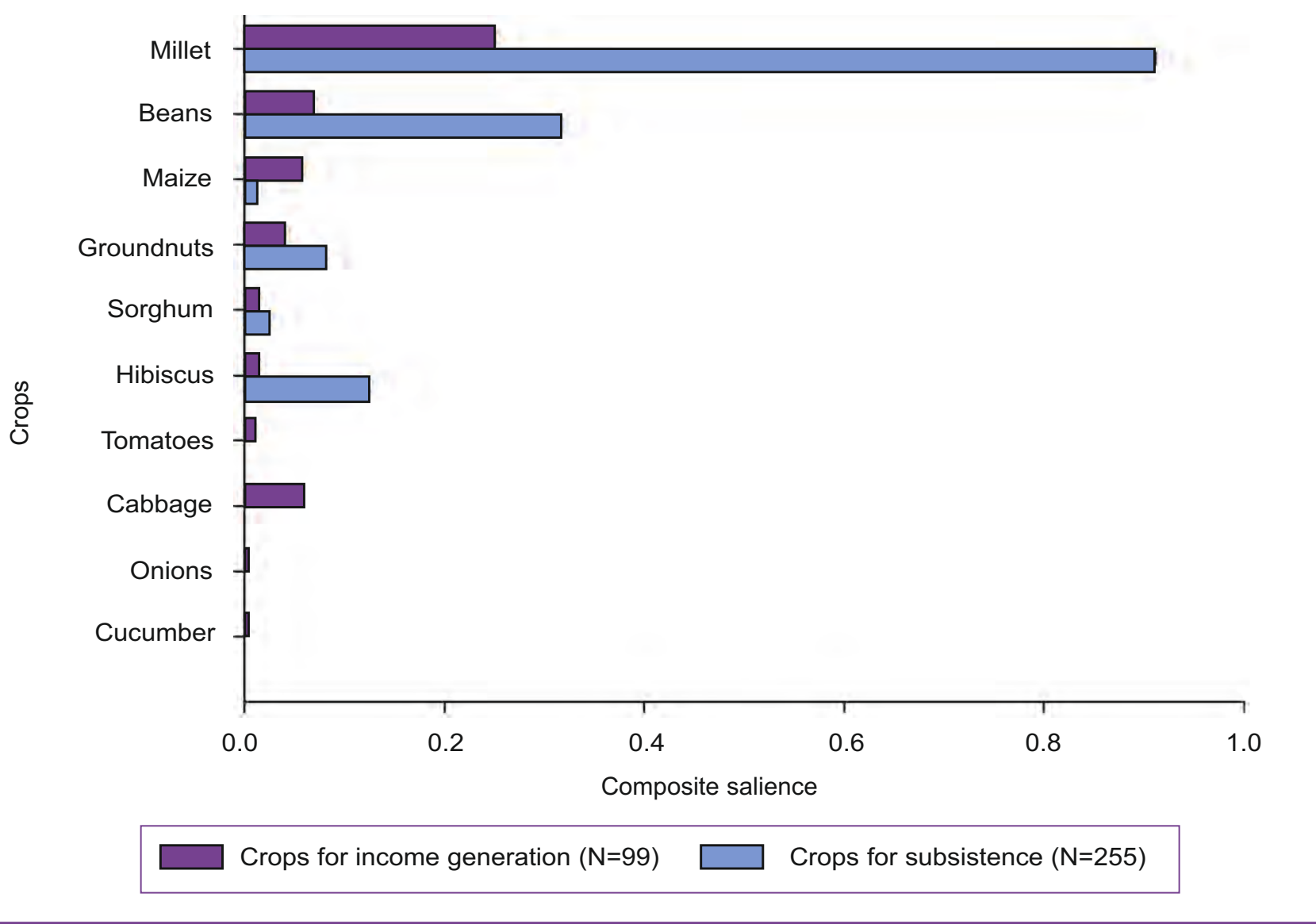

Fig. 3: Most important crops cultivated for income and for subsistence (salience calculated based on ranking and frequency of citation).

a third of the households sell or exchange some of their crops occasionally. This concerns mainly millet, beans, groundnuts and maize (Fig. 3). 12\% of the households do not practice arable agriculture at all.

The high total diversity of crops cultivated in the research area, combined with a low average number of crops produced within individual farms, indicates a variety of production strategies followed by local smallholders. The low within-farm crop diversity can be explained by the fact that under the local rainfall and soil fertility conditions (erratic and extremely low, respectively), only pearl millet and pulses may yield a stable, albeit low, production. While relying on these staple crops, some farmers experiment with other crops on field patches of slightly higher soil fertility. This can be seen as an attempt to adapt to major farming challenges in the core site. Examples include: diversification of crop rotations to cope with declining soil fertility or extending the cultivation period by crop diversification to reduce labour peaks and risk from erratic rainfalls. This experimentation furthermore reflects the growing importance of cash cropping. 


\section{Livestock ownership}

Livestock in the research area is largely kept for subsistence purposes and consists of cattle and goats. Chickens and donkeys are also kept but not considered in this factsheet. Indeed, among all livestockowning households, only 1 out of $\mathbf{3}$ sell any of their animals. These households generally sell less than 5 animals per year. Surprisingly, only $38 \%$ of the households own cattle and 30\% own goats. Among those households who do own livestock, three quarters have less than 20 goat and 20 cattle heads respectively. A very small group of 9 households (3\%) practices more intense livestock production with herds of over 50 heads, to a maximum of 100 goats and 200 cattle.

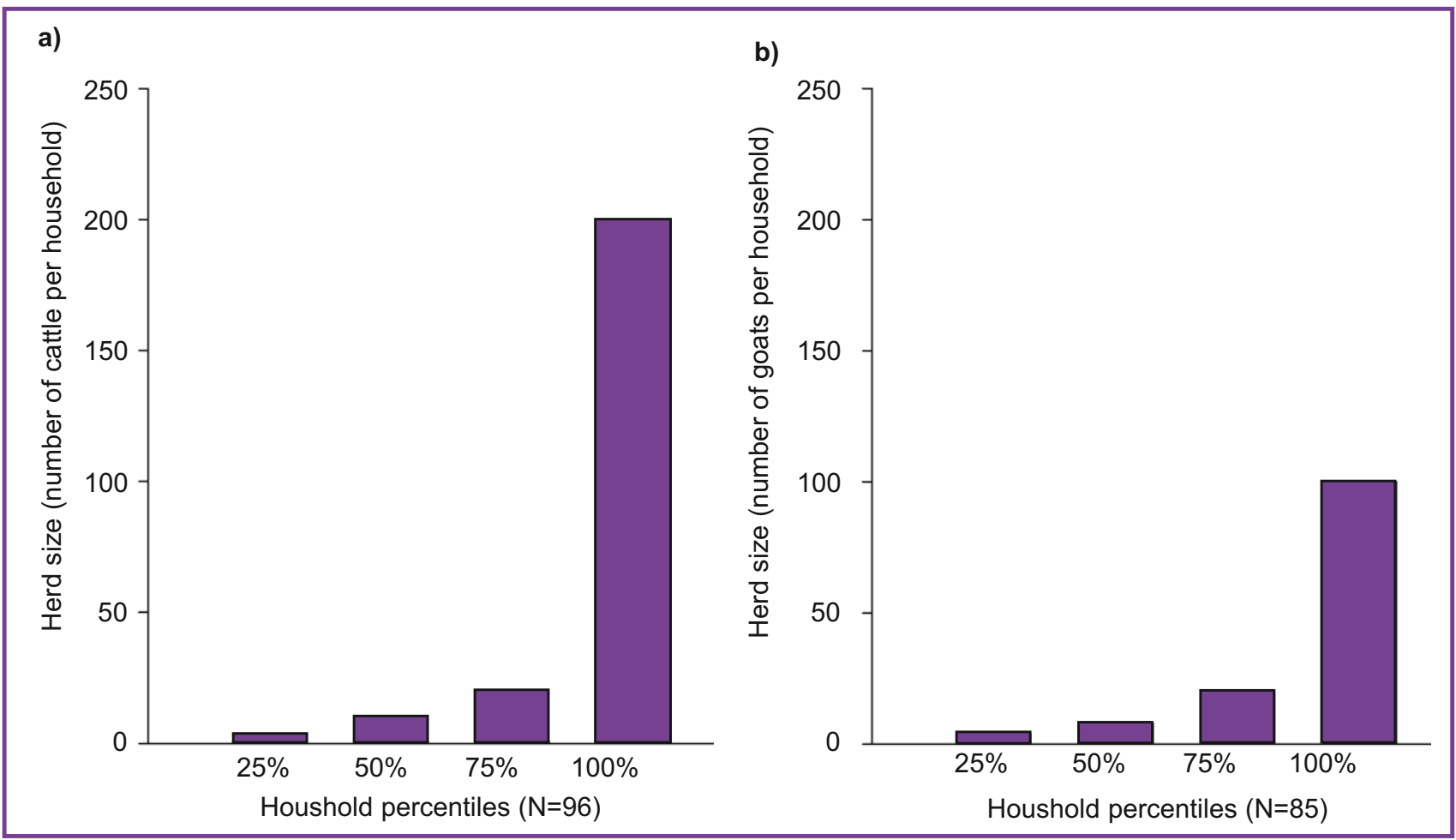

Fig. 4: Distribution of livestock ownership (a: cattle; b: goats).

\section{Acknowledgements}

This study was funded by the BMBF (The Future Okavango project). For details see authors' general acknowledgements in this volume.

\section{References}

FAO (2010) Alphabetical list of crops with botanical name and crop code. Appendix 4. In: World Programme for the Census of Agriculture Report. Accessed on 15

10.2013.,,http://www.fao.org/fileadmin/te mplates/ess/documents/world_census_o f agri-culture/appendix4 r7.pdf".

Ruthenberg, H. (1971): Farming Systems in the Tropics. -Oxford: Clandon Press. 